\title{
Donghaeana dokdonensis gen. nov., sp. nov., isolated from sea water
}

Correspondence

Jung-Hoon Yoon

jhyoon@kribb.re.kr

Tae-Kwang Oh

otk@kribb.re.kr

\author{
Jung-Hoon Yoon, So-Jung Kang, Choong-Hwan Lee and Tae-Kwang Oh \\ Korea Research Institute of Bioscience and Biotechnology (KRIBB), PO Box 115, Yusong, \\ Taejon, Korea
}

\begin{abstract}
A Gram-negative, non-motile, non-spore-forming and rod-shaped bacterial strain, DSW-6 ${ }^{\top}$, was isolated from sea water and subjected to a polyphasic study. Strain DSW-6 ${ }^{\top}$ grew optimally at $25^{\circ} \mathrm{C}$, in the presence of $2 \%(\mathrm{w} / \mathrm{v}) \mathrm{NaCl}$ and at $\mathrm{pH} 7 \cdot 0-8 \cdot 0$. It was characterized chemotaxonomically as having MK-6 as the predominant menaquinone and iso- $\mathrm{C}_{15: 0}$, anteiso- $\mathrm{C}_{15: 0}$, iso- $\mathrm{C}_{17: 0} 3-\mathrm{OH}$ and $\mathrm{C}_{15: 0}$ as the major fatty acids ( $>10 \%$ of total fatty acids). Major polar lipids were phosphatidylethanolamine, unidentified phospholipids and amino-group-containing lipids that are ninhydrin-positive. The DNA G + C content was $36 \cdot 9$ mol\%. Phylogenetic analyses based on 16S rRNA gene sequences showed that strain DSW- $6^{\top}$ forms an independent line of descent within the family Flavobacteriaceae. The 16S rRNA gene sequence of strain DSW- ${ }^{\top}$ exhibited similarity values of less than $94 \cdot 7 \%$ to the sequences of other members of the family Flavobacteriaceae. Strain DSW $-6^{\top}$ could be distinguished from other phylogenetically related genera by differences in several phenotypic properties. Therefore, in view of the combined phenotypic and phylogenetic data, it is proposed that strain DSW- $6^{\top}$ $\left(=\right.$ KCTC $12402^{\top}=$ DSM $\left.17205^{\top}\right)$ represents a novel genus and species, Donghaeana dokdonensis gen. nov., sp. nov.
\end{abstract}

Dokdo is an island located in the East Sea, Korea. Restriction of access to the island for a long time may have resulted in interesting microbial diversity, which led us to investigate the microbial community of soils and sea water from the island. In the course of screening micro-organisms from sea water in Dokdo, a bacterial strain, DSW-6 ${ }^{\mathrm{T}}$, belonging to the Cytophaga-Flavobacterium-Bacteroides (CFB) group, was isolated and characterized. CFB is one of the major bacterial groups in marine environments (Bowman et al., 1997; Glöckner et al., 1999; Kirchman, 2002). Accordingly, the aim of the present work was to determine the exact taxonomic position of strain DSW $-6^{\mathrm{T}}$ by a polyphasic taxonomic characterization.

Sea water provided the source for isolation of bacterial strains. A standard dilution plating technique on marine agar 2216 (MA; Difco) and incubation at $20^{\circ} \mathrm{C}$ were used to isolate strain DSW $-6^{\mathrm{T}}$. To investigate its morphological and physiological characteristics, strain DSW- $6^{\mathrm{T}}$ was routinely cultivated on MA at $25^{\circ} \mathrm{C}$. Cell morphology was examined by light microscopy (Nikon E600) and transmission electron microscopy. Transmission electron microscopy was also used to determine whether flagella are present in

Published online ahead of print on 9 September 2005 as DOI 10.1099/ijs.0.63847-0.

The GenBank/EMBL/DDBJ accession number for the 16S rRNA gene sequence of strain DSW-6 ${ }^{\top}$ is DQ0 17065 . cells from exponentially growing cultures. Gliding motility was investigated as described by Bowman (2000). The Gram reaction was determined by using the bioMérieux Gram Stain kit according to the manufacturer's instructions. The $\mathrm{pH}$ range for growth was determined in marine broth 2216 (MB; Difco) that was adjusted to various $\mathrm{pH}$ values ( $\mathrm{pH} 4 \cdot 5-10 \cdot 5$ at intervals of $0.5 \mathrm{pH}$ units). The $\mathrm{pH}$ was adjusted prior to sterilization to various levels by the addition of $\mathrm{HCl}$ or $\mathrm{Na}_{2} \mathrm{CO}_{3}$. Growth in the absence of $\mathrm{NaCl}$ was investigated in R2A agar (Difco) and trypticase soy broth prepared according to the formula of the Difco medium except that no $\mathrm{NaCl}$ was used. Growth at various $\mathrm{NaCl}$ concentrations $[0.5 \%(\mathrm{w} / \mathrm{v})$ and $1.0-10.0 \%(\mathrm{w} / \mathrm{v})$ at intervals of $1.0 \%$ ] was investigated in $\mathrm{MB}$ and trypticase soy broth (Difco). Growth at various temperatures $\left(4-35^{\circ} \mathrm{C}\right)$ was measured on MA. Growth under anaerobic conditions was determined after incubation in an anaerobic chamber on MA and on MA supplemented with nitrate that had both been prepared anaerobically in a nitrogen atmosphere. Catalase and oxidase activities and hydrolysis of casein and starch were determined as described by Cowan \& Steel (1965). Hydrolysis of Tweens 20, 40, 60 and 80 was determined as described by Cowan \& Steel (1965) with a modification that artificial sea water was used instead of distilled water. Hydrolysis of aesculin, gelatin and urea and nitrate reduction were determined as described by Lanyi (1987) using artificial sea water. Artificial sea water contained (per litre of distilled water) $23.6 \mathrm{~g} \mathrm{NaCl}, 0.64 \mathrm{~g} \mathrm{KCl}$, 
$4.53 \mathrm{~g} \mathrm{MgCl}_{2} \cdot 6 \mathrm{H}_{2} \mathrm{O}$, 5.94 $\mathrm{g}^{\mathrm{MgSO}_{4} .7 \mathrm{H}_{2} \mathrm{O}}$ and $1.3 \mathrm{~g}$ $\mathrm{CaCl}_{2} \cdot 2 \mathrm{H}_{2} \mathrm{O}$ (Bruns et al., 2001). Hydrolysis of hypoxanthine, tyrosine and xanthine was investigated on MA with the substrate concentrations described by Cowan \& Steel (1965), i.e. $0 \cdot 4,0 \cdot 5$ and $0 \cdot 4 \%(\mathrm{w} / \mathrm{v})$, respectively. The production of $\mathrm{H}_{2} \mathrm{~S}$ was tested as described previously (Bruns et al., 2001). The presence of flexirubin-type pigments was investigated as described by Reichenbach (1992). Freezedried cells were extracted with acetone/methanol $(1: 1, \mathrm{v} / \mathrm{v})$ to investigate the presence of carotenoid pigments; after removal of cells by centrifugation, the absorption spectrum of the supernatant was examined on a Beckman Coulter DU800 spectrophotometer. Acid production from carbohydrates was determined as described by Leifson (1963). Growth on several substrates was tested in a basal medium containing $0.2 \mathrm{~g} \mathrm{NaNO}_{3}, 0.2 \mathrm{~g} \mathrm{NH}_{4} \mathrm{Cl}$ and $0.05 \mathrm{~g}$ yeast extract in $1000 \mathrm{ml}$ artificial sea water (Bruns et al., 2001) as described by Suzuki et al. (2001). Susceptibility to antibiotics was tested on MA plates using antibiotic discs containing the following concentrations: polymyxin B, 100 $\mathrm{U}$; streptomycin, $50 \mu \mathrm{g}$; penicillin G, $20 \mathrm{U}$; chloramphenicol, $100 \mu \mathrm{g}$; ampicillin, $10 \mu \mathrm{g}$; cephalothin, $30 \mu \mathrm{g}$; gentamicin, $30 \mu \mathrm{g}$; novobiocin, $5 \mu \mathrm{g}$; tetracycline, $30 \mu \mathrm{g}$; kanamycin, $30 \mu \mathrm{g}$; lincomycin, $15 \mu \mathrm{g}$; oleandomycin, $15 \mu \mathrm{g}$; neomycin, $30 \mu \mathrm{g}$; carbenicillin, $100 \mu \mathrm{g}$. Other physiological and biochemical tests were performed using the API ZYM and API 20E systems (bioMérieux); cell suspension to inoculate the systems was prepared by using cells cultivated for 3 days at $25^{\circ} \mathrm{C}$ on MA and artificial sea water (Bruns et al., 2001).

Cell biomass of strain DSW $-6^{\mathrm{T}}$ for DNA extraction and for isoprenoid quinone and polar lipid analyses was obtained by cultivation for 2 days in $\mathrm{MB}$ at $25^{\circ} \mathrm{C}$. Chromosomal DNA was isolated and purified according to the method described previously (Yoon et al., 1996), with the exception that RNase T1 was used in combination with RNase A to minimize contamination with RNA. The $16 \mathrm{~S}$ rRNA gene was amplified by PCR using two universal primers as described previously (Yoon et al., 1998). Sequencing of the amplified 16S rRNA gene and phylogenetic analysis were performed as described by Yoon et al. (2003). Isoprenoid quinones were extracted according to the method of Komagata \& Suzuki (1987) and analysed using reversephase HPLC and a YMC ODS-A $(250 \times 4.6 \mathrm{~mm})$ column. Polar lipids were extracted according to the procedures described by Minnikin et al. (1984) and identified by twodimensional TLC followed by spraying with appropriate detection reagents (Minnikin et al., 1984; Komagata \& Suzuki, 1987). For fatty acid methyl ester analysis, cell mass of strain DSW $-6^{\mathrm{T}}$ was harvested from agar plates after incubation for 3 days at $25^{\circ} \mathrm{C}$ on MA. The fatty acid methyl esters were extracted and prepared according to the standard protocol of the MIDI/Hewlett Packard Microbial Identification System (Sasser, 1990). The DNA G+C content was determined by the method of Tamaoka \& Komagata (1984) with a modification that DNA was hydrolysed and the resulting nucleotides were analysed by reverse-phase HPLC.

Morphological, cultural, physiological and biochemical characteristics of strain DSW- $6^{\mathrm{T}}$ are given in the species description (see later) or are shown in Table 1, together with those of some phylogenetically related genera. The acetone/ methanol extract of the freeze-dried cells showed absorption maxima at 413,441 and $465 \mathrm{~nm}$, demonstrating the presence of carotenoids. Strain DSW $-6^{\mathrm{T}}$ produced no flexirubin-type pigments. The almost complete $16 \mathrm{~S}$ rRNA gene sequence of strain DSW $-6^{\mathrm{T}}$ determined in this study comprised 1481 nucleotides, representing approximately $96 \%$ of the Escherichia coli $16 \mathrm{~S}$ rRNA sequence. In the phylogenetic trees based on 16S rRNA gene sequences, strain DSW- $6^{\mathrm{T}}$ formed a cluster with unidentified Flavobacteriaceae bacterium SW256, Nonlabens tegetincola and 'Stenothermobacter spongiae' with which it exhibited $16 \mathrm{~S}$ rRNA gene sequence similarity values of $93 \cdot 3-98 \cdot 2 \%$ (Fig. 1). This cluster joined the clade comprising Psychroflexus species by a bootstrap confidence level of $54 \cdot 2 \%$ (Fig. 1). Strain DSW $-6^{\mathrm{T}}$ exhibited $16 \mathrm{~S}$ rRNA gene sequence similarity levels of less than $90 \cdot 8 \%$ with respect to other species used in the phylogenetic analysis.

The predominant isoprenoid quinone detected in strain DSW- $6^{\mathrm{T}}$ was menaquinone-6 (MK-6) at a peak area ratio of approximately $94 \%$. The cellular fatty acid profile of strain DSW $-6^{\mathrm{T}}$ comprised ( $>1 \%$ of total fatty acids) branched fatty acids iso- $\mathrm{C}_{15: 0}(19 \cdot 2 \%)$, anteiso- $\mathrm{C}_{15: 0}(11 \cdot 1 \%)$, iso$\mathrm{C}_{17: 1} \omega 9 c(3 \cdot 5 \%)$, iso- $\mathrm{C}_{16: 0}(1 \cdot 5 \%)$ and iso- $\mathrm{C}_{16: 1}(1 \cdot 3 \%)$; hydroxyl fatty acids iso- $\mathrm{C}_{17: 0} 3-\mathrm{OH}(10 \cdot 5 \%)$, iso- $\mathrm{C}_{15: 0} 3-$ $\mathrm{OH}(6 \cdot 7 \%)$, iso- $\mathrm{C}_{16: 0} 3-\mathrm{OH}(3 \cdot 5 \%), \mathrm{C}_{15: 0} 3-\mathrm{OH}(3 \cdot 3 \%)$, $\mathrm{C}_{17: 0} 2-\mathrm{OH}(3 \cdot 0 \%), \mathrm{C}_{15: 0} 2-\mathrm{OH}(1 \cdot 8 \%)$ and $\mathrm{C}_{16: 0} 2-\mathrm{OH}$ $(1 \cdot 5 \%)$; straight-chain fatty acids $\mathrm{C}_{15: 0}(10 \cdot 2 \%), \mathrm{C}_{18: 0}$ $(2 \cdot 0 \%)$ and $\mathrm{C}_{16: 0}(1 \cdot 5 \%)$; unsaturated fatty acids $\mathrm{C}_{15: 1} \omega 6 \mathrm{c}$ $(3.7 \%), \mathrm{C}_{17: 1} \omega 6 c(2.9 \%)$ and $\mathrm{C}_{18: 1} \omega 5 c(1.7 \%)$; and summed feature 3 comprising $\mathrm{C}_{16: 1} \omega 7 c$ and/or iso- $\mathrm{C}_{15: 0}$ $2-\mathrm{OH}(7 \cdot 1 \%)$. The phospholipid identified in strain DSW $-6^{\mathrm{T}}$ was phosphatidylethanolamine, and other major polar lipids were three unidentified phospholipids and three amino-group-containing lipids that were ninhydrinpositive. The DNA G $+\mathrm{C}$ content of strain DSW $-6^{\mathrm{T}}$ was $36 \cdot 9 \mathrm{~mol} \%$.

The predominant menaquinone type (MK-6) of strain DSW $-6^{\mathrm{T}}$ was the same as that of all members of the family Flavobacteriaceae (Bowman et al., 1998; Bernardet et al., 2002). Phylogenetic analyses based on three different algorithms revealed that strain DSW $-6^{\mathrm{T}}$ forms a distinct phylogenetic lineage within the family Flavobacteriaceae (Fig. 1). The 16S rRNA gene sequence similarity values were too low (less than $94 \cdot 7 \%$ ) to assign strain DSW $-6^{\mathrm{T}}$ to any recognized genus in the family. The fatty acid profiles, particularly proportions of the major fatty acids, also distinguished strain DSW $-6^{\mathrm{T}}$ from the phylogenetically related genera Psychroflexus, Salegentibacter, Mesonia, Gillisia, Aquimarina, Stanierella and Gaetbulimicrobium, although differences might partly be caused by different cultivation 
Table 1. Differential phenotypic characteristics of Donghaeana dokdonensis gen. nov. and related genera

Genus: 1, Donghaeana dokdonensis gen. nov.; 2, Psychroflexus, data from Bowman et al. (1998) and Donachie et al. (2004); 3, Salegentibacter, data from Nedashkovskaya et al. (2004, 2005b); 4, Mesonia, data from Nedashkovskaya et al. (2003); 5, Gillisia, data from Van Trappen et al. (2004) and Nedashkovskaya et al. (2005c); 6, Aquimarina, data from Nedashkovskaya et al. (2005a); 7, Stanierella, data from Reichenbach (1989) and Nedashkovskaya et al. (2005a). All genera are positive for alkaline phosphatase (not determined for Stanierella), oxidase (variable for Psychroflexus) and hydrolysis of Tween 80 (variable for Psychroflexus). All genera are negative for acid production from D-cellobiose. +, Positive reaction; -, negative reaction; ND, not determined; $\mathrm{V}$, variable reaction.

\begin{tabular}{|c|c|c|c|c|c|c|c|}
\hline Characteristic & 1 & 2 & 3 & 4 & 5 & 6 & 7 \\
\hline Gliding motility & - & $\mathrm{V}$ & - & - & - & + & - \\
\hline Cell size $(\mu \mathrm{m})$ & $1 \cdot 0-30 \cdot 0$ & $2 \cdot 0-50 \cdot 0$ & $2 \cdot 5-5 \cdot 3$ & $1 \cdot 6-2 \cdot 3$ & $3 \cdot 0-4 \cdot 0$ & $5-7$ & $1-40$ \\
\hline Pigmentation & Orange & Orange & Yellow & Yellow & Yellow & $\begin{array}{l}\text { Dark yellow } \\
\text { to brown }\end{array}$ & Orange-red \\
\hline $\begin{array}{l}\text { Growth at }>10 \% \\
\mathrm{NaCl}\end{array}$ & - & $\mathrm{V}$ & $\mathrm{V}$ & + & $\mathrm{V}$ & - & - \\
\hline Growth at $37^{\circ} \mathrm{C}$ & - & $\mathrm{V}$ & $\mathrm{V}$ & - & - & - & - \\
\hline Nitrate reduction & - & $\mathrm{V}$ & $\mathrm{V}$ & - & - & - & - \\
\hline \multicolumn{8}{|l|}{ Hydrolysis of: } \\
\hline Agar & - & $-*$ & - & - & - & - & + \\
\hline Casein & + & $\mathrm{V}$ & $\mathrm{V}$ & + & $\mathrm{V}$ & + & $+\ddagger$ \\
\hline Gelatin & - & $\mathrm{V}$ & + & + & + & + & + \\
\hline Starch & + & $+^{*}$ & + & - & - & + & - \\
\hline Urea & - & $\mathrm{V}$ & - & - & $\mathrm{V}$ & - & - \\
\hline Tween 20 & + & $\mathrm{ND}$ & + & + & $\mathrm{V}$ & + & + \\
\hline Tween 40 & + & ND & + & + & $\mathrm{V}$ & + & + \\
\hline \multicolumn{8}{|l|}{ Acid production from: } \\
\hline D-Glucose & - & $\mathrm{V}$ & $\mathrm{V}$ & - & $\mathrm{V}$ & - & - \\
\hline Streptomycin & + & ND & $\mathrm{V}$ & ND & $\mathrm{V}$ & ND & + \\
\hline Tetracycline & + & $\mathrm{ND}$ & + & ND & $\mathrm{V}$ & $\mathrm{ND}$ & $\mathrm{ND}$ \\
\hline $\begin{array}{l}\text { Major fatty acid(s)§ } \\
(>10 \%)\end{array}$ & $\begin{array}{c}\mathrm{i}-\mathrm{C}_{15: 0} \\
\text { ai- } \mathrm{C}_{15: 0} \\
\mathrm{i}-\mathrm{C}_{17: 0} 3-\mathrm{OH}, \\
\mathrm{C}_{15: 0}\end{array}$ & $\begin{array}{c}\text { ai- } \mathrm{C}_{15: 0}, \\
\text { ai-C } \mathrm{C}_{15: 1} \omega 10 c \\
\mathrm{i}-\mathrm{C}_{16: 0} 3-\mathrm{OH}\end{array}$ & $\begin{array}{l}\mathrm{i}-\mathrm{C}_{15: 0} \\
\mathrm{i}-\mathrm{C}_{15: 1} \\
\mathrm{C}_{16: 1} \omega 7 c \\
\text { or } \mathrm{i}-\mathrm{C}_{15: 1}\end{array}$ & $\begin{array}{c}\mathrm{i}-\mathrm{C}_{15: 0}, \\
\mathrm{i}-\mathrm{C}_{17: 0} 3-\mathrm{OH}\end{array}$ & $\begin{array}{l}\mathrm{C}_{17: 0} 2-\mathrm{OH} \\
\quad \text { or } \mathrm{i}-\mathrm{C}_{15: 1}\end{array}$ & $\begin{array}{c}\mathrm{i}-\mathrm{C}_{17: 0} 3-\mathrm{OH} \\
\mathrm{i}-\mathrm{C}_{15: 0} \\
\mathrm{i}-\mathrm{C}_{15: 1} \\
\mathrm{i}-\mathrm{C}_{17: 1} \omega 9 c\end{array}$ & $\begin{array}{c}\mathrm{i}-\mathrm{C}_{17: 0} 3-\mathrm{OH}, \\
\mathrm{i}-\mathrm{C}_{15: 0} \\
\mathrm{i}-\mathrm{C}_{17: 1} \omega 7 c\end{array}$ \\
\hline $\begin{array}{l}\text { DNA G + C content } \\
(\mathrm{mol} \%)\end{array}$ & $36 \cdot 9$ & $32-36$ & $37-38$ & $32 \cdot 7-34 \cdot 0$ & $36-39$ & $31 \cdot 6-32 \cdot 5$ & 34 \\
\hline
\end{tabular}

${ }^{*}$ Data for Psychroflexus torquis and Psychroflexus gondwanensis.

$\dagger$ Data for Gillisia limnaea.

$\ddagger$ Data taken from Nedashkovskaya et al. (2005a); a different result was obtained by Reichenbach (1989).

§i, iso; ai, anteiso. Data for the genus Salegentibacter are those of Salegentibacter holothuriorum and Salegentibacter mishustinae. 


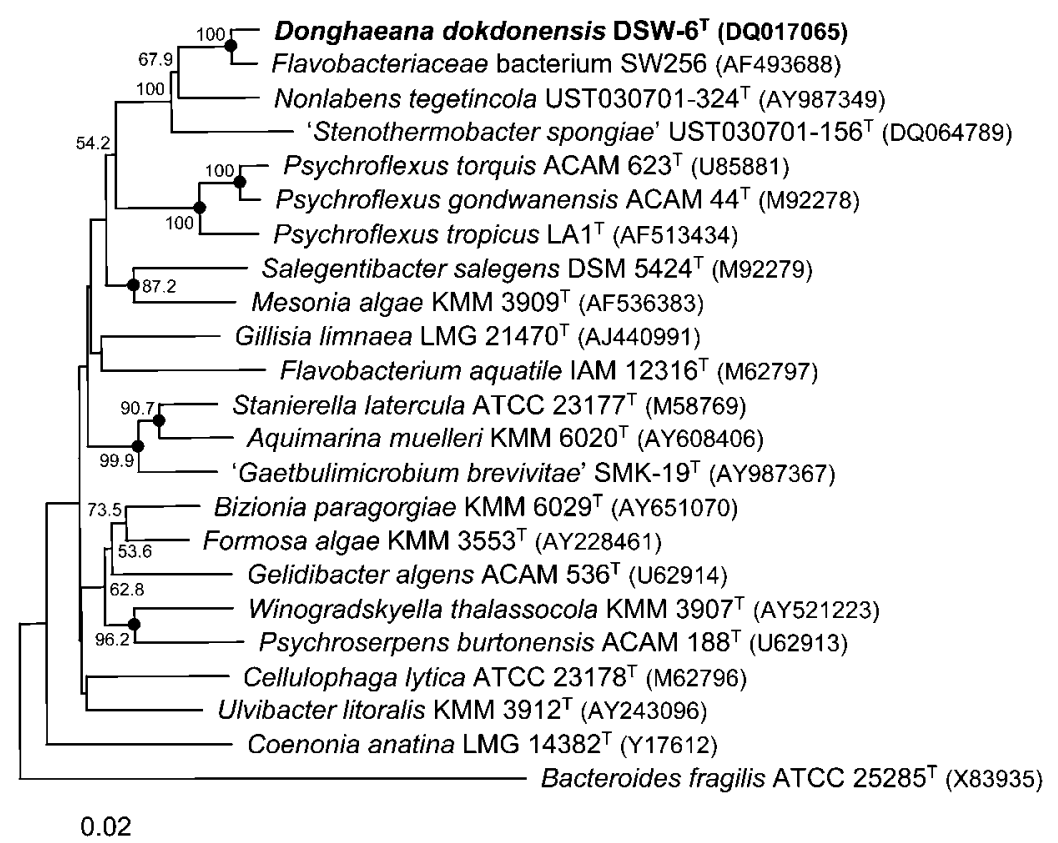

Fig. 1. Neighbour-joining tree based on 16S rRNA gene sequences showing the phylogenetic positions of strain DSW $-6^{\top}$ and representatives of some other related taxa. Bootstrap values (expressed as percentages of 1000 replications) greater than $50 \%$ are shown at the branching points. Bacteroides fragilis ATCC $25285^{\top}$ was used as an outgroup. Dots indicate that the corresponding nodes were also recovered in the trees generated with the maximum-likelihood and maximum-parsimony algorithms. Scale bar, 0.02 substitutions per nucleotide position. conditions (Table 1). Strain DSW $-6^{\mathrm{T}}$ was also differentiated from phylogenetically related genera by differences in several phenotypic properties as shown in Table 1. Low 16S rRNA gene sequence similarity values between strain DSW$6^{\mathrm{T}}$ and all other members of the family Flavobacteriaceae, together with differential phenotypic properties, suggest that strain DSW $-6^{\mathrm{T}}$ constitutes a new genus and species in the family Flavobacteriaceae, for which the name Donghaeana dokdonensis gen. nov., sp. nov. is proposed.

\section{Description of Donghaeana gen. nov.}

Donghaeana (Dong.hae.a'na. Donghae, the Korean name of the East Sea in Korea; L. fem. suff. -ana, suffix used with the sense of belonging to; N.L. fem. adj. used as a substantive Donghaeana pertaining to the East Sea of Korea, where Dokdo is located).

Cells are Gram-negative, non-spore-forming, rods or elongated rods $(0 \cdot 4-0 \cdot 6 \times 1 \cdot 0-30 \cdot 0 \mu \mathrm{m})$. Strictly aerobic. The predominant menaquinone is MK-6. The major polar lipids are phosphatidylethanolamine, unidentified phospholipids and amino-group-containing lipids that are ninhydrinpositive. The type species is Donghaeana dokdonensis.

\section{Description of Donghaeana dokdonensis sp. nov.}

Donghaeana dokdonensis (dok.do.nen'sis. N.L. fem. adj. dokdonensis of Dokdo, a Korean island, where the type strain was isolated).

Exhibits the following properties in addition to those given in the genus description. Cells are non-motile. Colonies on MA are circular, convex, glistening, smooth, orangecoloured and $0 \cdot 8-1.4 \mathrm{~mm}$ in diameter after incubation for 3 days at $25^{\circ} \mathrm{C}$. Growth occurs from 4 to $32^{\circ} \mathrm{C}$ with an optimum temperature of $25^{\circ} \mathrm{C}$. Optimal $\mathrm{pH}$ for growth is $7 \cdot 0-8 \cdot 0$; growth is observed at $\mathrm{pH} 5 \cdot 5$, but not at $\mathrm{pH} 5 \cdot 0$. Optimal growth occurs in the presence of $2 \%(\mathrm{w} / \mathrm{v}) \mathrm{NaCl}$; growth does not occur in the absence of $\mathrm{NaCl}$ and in the presence of greater than $8 \%(\mathrm{w} / \mathrm{v}) \mathrm{NaCl}$. Anaerobic growth does not occur on MA and on MA supplemented with nitrate. Aesculin and Tween 60 are hydrolysed, but hypoxanthine, xanthine and L-tyrosine are not. Indole is not produced. Arginine dihydrolase, lysine decarboxylase, ornithine decarboxylase and tryptophan deaminase are absent. In assays with the API ZYM system, esterase (C4), esterase lipase (C8), leucine arylamidase, valine arylamidase, acid phosphatase and naphthol-AS-BI-phosphohydrolase are present, but lipase (C14), cystine arylamidase, trypsin, $\alpha$-chymotrypsin, $\alpha$-galactosidase, $\beta$-glucuronidase, $\alpha$-glucosidase, $\beta$-glucosidase, $N$-acetyl- $\beta$-glucosaminidase, $\alpha$-mannosidase and $\alpha$-fucosidase are absent. Susceptible to chloramphenicol, cephalothin, novobiocin and lincomycin, but not to polymyxin B, ampicillin, gentamicin, kanamycin or neomycin. Growth occurs on peptone and tryptone as the sole carbon and nitrogen sources, but not on D-ribose, Dgalactose, D-fructose, D-cellobiose, D-trehalose, Casamino acids, DL-aspartate, L-glutamate, L-leucine or L-proline. Acid is not produced from L-arabinose, D-fructose, Dgalactose, lactose, D-mannose, melibiose, D-melezitose, D-raffinose, L-rhamnose, D-ribose, sucrose, D-trehalose, Dxylose, D-mannitol, D-sorbitol or myo-inositol. The major fatty acids ( $>10 \%$ of total fatty acids) are iso- $\mathrm{C}_{15: 0}$ $(19 \cdot 2 \%)$, anteiso- $\mathrm{C}_{15: 0}(11 \cdot 1 \%)$, iso- $\mathrm{C}_{17: 0} 3-\mathrm{OH}(10 \cdot 5 \%)$ and $\mathrm{C}_{15: 0}(10 \cdot 2 \%)$. The DNA G $+\mathrm{C}$ content is $36 \cdot 9 \mathrm{~mol} \%$. Other phenotypic properties are given in Table 1.

The type strain, DSW $-6^{\mathrm{T}}\left(=\mathrm{KCTC} 12402^{\mathrm{T}}=\mathrm{DSM} 17205^{\mathrm{T}}\right)$, was isolated from sea water. 


\section{Acknowledgements}

This work was supported by the 21C Frontier program of Microbial Genomics and Applications (grant MG05-0401-2-0) from the Ministry of Science and Technology (MOST) of the Republic of Korea. We are grateful to the Ulleung County Administration and the Cultural Heritage Administration of the Republic of Korea for aiding access to Dokdo.

\section{References}

Bernardet, J.-F., Nakagawa, Y. \& Holmes, B. (2002). Proposed minimal standards for describing new taxa of the family Flavobacteriaceae and emended description of the family. Int J Syst Evol Microbiol 52, 1049-1070.

Bowman, J. P. (2000). Description of Cellulophaga algicola sp. nov., isolated from the surfaces of Antarctic algae, and reclassification of Cytophaga uliginosa (ZoBell and Upham 1944) Reichenbach 1989 as Cellulophaga uliginosa comb. nov. Int J Syst Evol Microbiol 50, 1861-1868.

Bowman, J. P., McCammon, S. A., Brown, M. V., Nichols, D. S. \& McMeekin, T. A. (1997). Diversity and association of psychrophilic bacteria in Antarctic sea ice. Appl Environ Microbiol 63, 3068-3078.

Bowman, J. P., McCammon, S. A., Lewis, T., Skerratt, J. H., Brown, J. L., Nichols, D. S. \& McMeekin, T. A. (1998). Psychroflexus torquis gen. nov., sp. nov., a psychrophilic species from Antarctic sea ice, and reclassification of Flavobacterium gondwanense (Dobson et al. 1993) as Psychroflexus gondwanense gen. nov., comb. nov. Microbiology 144, 1601-1609.

Bruns, A., Rohde, M. \& Berthe-Corti, L. (2001). Muricauda ruestringensis gen. nov., sp. nov., a facultatively anaerobic, appendaged bacterium from German North Sea intertidal sediment. Int J Syst Evol Microbiol 51, 1997-2006.

Cowan, S. T. \& Steel, K. J. (1965). Manual for the Identification of Medical Bacteria. London: Cambridge University Press.

Donachie, S. P., Bowman, J. P. \& Alam, M. (2004). Psychroflexus tropicus sp. nov., an obligately halophilic Cytophaga-FlavobacteriumBacteroides group bacterium from an Hawaiian hypersaline lake. Int J Syst Evol Microbiol 54, 935-940.

Glöckner, F. O., Fuchs, B. M. \& Amann, R. (1999). Bacterioplankton compositions of lakes and oceans: a first comparison based on fluorescence in situ hybridization. Appl Environ Microbiol 65, 3721-3726.

Kirchman, D. L. (2002). The ecology of Cytophaga-Flavobacteria in aquatic environments. FEMS Microbiol Ecol 39, 91-100.

Komagata, K. \& Suzuki, K. (1987). Lipids and cell-wall analysis in bacterial systematics. Methods Microbiol 19, 161-203.

Lanyi, B. (1987). Classical and rapid identification methods for medically important bacteria. Methods Microbiol 19, 1-67.

Leifson, E. (1963). Determination of carbohydrate metabolism of marine bacteria. J Bacteriol 85, 1183-1184.

Minnikin, D. E., O'Donnell, A. G., Goodfellow, M., Alderson, G., Athalye, M., Schaal, A. \& Parlett, J. H. (1984). An integrated procedure for the extraction of bacterial isoprenoid quinones and polar lipids. J Microbiol Methods 2, 233-241.

Nedashkovskaya, O. I., Kim, S. B., Han, S. K. \& 7 other authors (2003). Mesonia algae gen. nov., sp. nov., a novel marine bacterium of the family Flavobacteriaceae isolated from the green alga Acrosiphonia sonderi (Kütz) Kornm. Int J Syst Evol Microbiol 53, 1967-1971.

Nedashkovskaya, O. I., Suzuki, M., Vancanneyt, M., Cleenwerck, I., Zhukova, N. V., Vysotskii, M. V., Mikhailov, V. V. \& Swings, J. (2004). Salegentibacter holothuriorum sp. nov., isolated from the edible holothurian Apostichopus japonicus. Int J Syst Evol Microbiol 54, 1107-1110.

Nedashkovskaya, O. I., Kim, S. B., Lysenko, A. M., Frolova, G. M., Mikhailov, V. V., Lee, K. H. \& Bae, K. S. (2005a). Description of Aquimarina muelleri gen. nov., sp. nov., and proposal of the reclassification of [Cytophaga] latercula Lewin 1969 as Stanierella latercula gen. nov., comb. nov. Int J Syst Evol Microbiol 55, 225-229.

Nedashkovskaya, O. I., Kim, S. B., Lysenko, A. M., Mikhailov, V. V., Bae, K. S. \& Kim, I. S. (2005b). Salegentibacter mishustinae sp. nov., isolated from the sea urchin Strongylocentrotus intermedius. Int J Syst Evol Microbiol 55, 235-238.

Nedashkovskaya, O. I., Kim, S. B., Lee, K. H., Mikhailov, V. V. \& Bae, K. S. (2005c). Gillisia mitskevichiae sp. nov., a novel bacterium of the family Flavobacteriaceae, isolated from sea water. Int J Syst Evol Microbiol 55, 321-323.

Reichenbach, H. (1989). Order Cytophagales Leadbetter 1974, $99^{\mathrm{AL}}$. In Bergey's Manual of Systematic Bacteriology, vol. 3, pp. 2011-2073. Edited by J. T. Staley, M. P. Bryant, N. Pfennig \& J. C. Holt. Baltimore: Williams \& Wilkins.

Reichenbach, H. (1992). The order Cytophagales. In The Prokaryotes. A Handbook on the Biology of Bacteria: Ecophysiology, Isolation, Identification, Applications, 2nd edn, pp. 3631-3675. Edited by A. Balows, H. G. Trüper, M. Dworkin, W. Harder \& K. H. Schleifer. New York: Springer.

Sasser, M. (1990). Identification of Bacteria by Gas Chromatography of Cellular Fatty Acids. Newark, DE: MIDI.

Suzuki, M., Nakagawa, Y., Harayama, S. \& Yamamoto, S. (2001). Phylogenetic analysis and taxonomic study of marine Cytophaga-like bacteria: proposal for Tenacibaculum gen. nov. with Tenacibaculum maritimum comb. nov. and Tenacibaculum ovolyticum comb. nov., and description of Tenacibaculum mesophilum sp. nov. and Tenacibaculum amylolyticum sp. nov. Int J Syst Evol Microbiol 51, 1639-1652.

Tamaoka, J. \& Komagata, K. (1984). Determination of DNA base composition by reverse-phase high-performance liquid chromatography. FEMS Microbiol Lett 25, 125-128.

Van Trappen, S., Vandecandelaere, I., Mergaert, J. \& Swings, J. (2004). Gillisia limnaea gen. nov., sp. nov., a new member of the family Flavobacteriaceae isolated from a microbial mat in Lake Fryxell, Antarctica. Int J Syst Evol Microbiol 54, 445-448.

Yoon, J.-H., Kim, H., Kim, S.-B., Kim, H.-J., Kim, W. Y., Lee, S. T., Goodfellow, M. \& Park, Y.-H. (1996). Identification of Saccharomonospora strains by the use of genomic DNA fragments and rRNA gene probes. Int J Syst Bacteriol 46, 502-505.

Yoon, J.-H., Lee, S. T. \& Park, Y.-H. (1998). Inter- and intraspecific phylogenetic analysis of the genus Nocardioides and related taxa based on 16S rRNA gene sequences. Int J Syst Bacteriol 48, 187-194.

Yoon, J.-H., Kang, K. H. \& Park, Y.-H. (2003). Psychrobacter jeotgali sp. nov., isolated from jeotgal, a traditional Korean fermented seafood. Int J Syst Evol Microbiol 53, 449-454. 